\title{
Effect of different irrigation regimes on the quality attributes of monovarietal virgin olive oil from cv. "Cobrançosa"
}

\author{
By A.A. Fernandes-Silva ${ }^{1,2, *}$, J.B. Gouveia ${ }^{3}$,P. Vasconcelos $^{3}$, T.C. Ferreira ${ }^{4}$ \\ and F.J. Villalobos ${ }^{5,6}$ \\ ${ }^{1}$ CITAB-Centre for the Research and Technology of Agro-Environment and Biological Sciences, University \\ of Trás-os-Montes e Alto Douro, 5001-801 Vila Real, Portugal \\ ${ }^{2}$ School of Agriculture and Veterinary Sciences, Department of Agronomy, University of Trás-os-Montes \\ e Alto Douro, 5001-801 Vila Real, Portugal \\ ${ }^{3}$ LET-Technical Studies Laboratory - Institute of Agronomy, Technical University of Lisbon; Tapada da \\ Ajuda, 1349 Lisbon, Portugal \\ ${ }^{4}$ International Consultant, Climate Change Adaptation. 4, New Houses, Aston Rd, TF11 8DX, Shifnal, \\ Shrops, UK \\ ${ }^{5}$ Departamento de Agronomía, Universidad de Cordoba, Apartado 3048, Cordoba 14080, Spain \\ ${ }^{6}$ Instituto de Agricultura Sostenible, CSIC, Apartado 4084, Cordoba 14080, Spain \\ * Corresponding author: anaaf@utad.pt
}

\section{RESUMEN}

Efecto de diferentes regímenes de riego sobre los índices de calidad del aceite de oliva de cv. "Cobrançosa"

El objetivo del estudio fue evaluar el efecto de distintas estrategias de riego en la composición y la calidad del aceite de oliva virgen de cv. Cobrançosa, integrado en una denominación de origen protegida de «Azeite de Trás-osMontes», en el noreste de Portugal. Tres tratamientos de riego fueron aplicados: T2-riego total, el olivo recibió el equivalente estacional de agua al $100 \%$ de la evapotranspiración estimada del cultivo (ETc), T1-riego continuo deficitario (30\% de la ETc) y el tratamiento T0-de secano. Los datos fueron recolectados a partir de dos campañas agrícolas consecutivas (2005-2006). Los regímenes de riego tuvieron un efecto menor en los índices de calidad estándar (ácidos grasos libres, índice de peróxidos, $\mathrm{K}_{232}$ y $\mathrm{K}_{270}$ ) del aceite de oliva y en la composición de ácidos grasos. Los polifenoles totales disminuyeron hasta el tratamiento T2, y se relacionaron fuertemente con el integral de estrés hídrico, lo que sugiere que el efecto del riego sobre esta variable se produce a lo largo de la temporada de cultivo y no sólo durante la fase de acumulación de aceite. Una estrategia de riego deficitario continuo con sólo $30 \%$ de la ETc máxima puede tener un efecto beneficioso, ya que aumentó la producción de aceite de oliva a más del doble que en condiciones de secano, mientras que la calidad del aceite de oliva fue similar.

PALABRAS CLAVE: Aceite de oliva virgen - Cv. Cobrançosa - Índices de calidad - Riego.

\section{ABSTRACT}

Effect of different irrigation regimes on the quality attributes of monovarietal virgin olive oil of cv. "Cobrançosa"

The aim of this study was to assess the effect of different irrigation strategies in virgin olive oil (VOO) composition and quality of Cv. Cobrançosa, integrated in a protected denomination of origin of "Azeite de Trás-os-Montes" in the Northeast of Portugal. Three irrigation treatments were applied: T2-full irrigation that received a seasonal water equivalent to $100 \%$ of estimated crop evapotranspiration $\left(\mathrm{ET}_{\mathrm{c}}\right)$, T1-continuous deficit irrigation $\left(30 \% \mathrm{ET}_{\mathrm{c}}\right)$ and $\mathrm{TO}$ rainfed treatment. Data were collected from two consecutive crop years (2005-2006). Irrigation regimes had a minor effect on standard quality indices (free fatty acids, peroxide value, $\mathrm{K}_{232}$ and $\mathrm{K}_{270}$ ) of $\mathrm{VOO}$ and in fatty acid composition. Total polyphenols decreased up to treatment T2, and were strongly related to the water stress integral, suggesting that the effect of irrigation on this variable occurs along the crop season and not just during the oil accumulation phase. A strategy of continuous deficit irrigation with only $30 \%$ of maximum ETc may have an advantageous effect, as it increased oil yield to more than double that of rainfed conditions while VOO quality was similar.

KEY-WORDS: cv. Cobrançosa - Irrigation - Quality indices - Virgin olive oil.

\section{INTRODUCTION}

Since time immemorial virgin olive oil (VOO) has been considered an essential ingredient of Mediterranean diet because of its special characteristics. In recent years, the consumption of VOO and table olives has steadily increased, even in countries that do not have such tradition, due to its associated healthy properties, namely its beneficial effect on protection against cardiovascular and neurodegenerative diseases (Pérez-Jiménez et al., 2007), and its potential role in reducing the potential risk of several cancers (Menendez et al., 2006). These beneficial effects are related to the characteristic fatty acid composition and the presence of minor components, such as squalane, phytosterols and antioxidant molecules, such as tocopherols and other phenolic compounds (Owen et al., 2000). Moreover, it is widely known 
that the quality characteristics of extra-virgin olive oils derive from concomitant action of various agronomical factors such as olive variety (Vinha et al., 2005), climatic conditions during growth (Mousa et al., 1996), degree of maturation (Bonoli et al., 2004) and agronomic practices related to irrigation management (Tovar et al., 2002; Servilli, et al., 2007; Gómez-Rico et al., 2009).

In recent years, olive (Olea europaea L.) cultivation is steadily expanding in many countries in response to increased oil consumption, and many agronomic practices have been changed for improving the management of the intensive cultivation systems aimed at increasing yield and reducing the costs. One of the most important changes that are currently occurring in olive cultivation is the expansion of irrigated orchards. Despite the olive tree to cope with severe and prolonged drought, it is well-known that a lack of water decreases yield and fruit size (Pastor et al., 1996) and there is evidence that conditions of mild water deficit, imposed with deficit irrigation strategies (DI) have a small impact on yield, while saving an important volume of water applied, and therefore increasing the water use efficiency (Iniesta et al., 2009). Recently, Fernandes-Silva et al. (2010) showed that a strategy of a continuous DI, reduced oil yield only $25 \%$ as compared to maximum irrigation, while it allowed saving $60 \%$ of applied water, which is in accordance with previous reports related to other DI strategies and cultivars (Wahbi et al., 2005; Gucci et al., 2007). Although, several studies agree on the positive effect of DI strategies on growth and yield, they differ in terms of the effect of irrigation on olive oil quality. For example, previous studies on the effect of irrigation on the fatty acid composition are controversial, some reporting no effect (Patumi et al., 1999; Motilva et al., 2000; Magliulo et al., 2003) while others indicated that irrigation can modify the fatty acid profile (Faci et al., 2002; Tognetti et al., 2007 ), perhaps in relation to differential responses of cultivars to environmental factors, whereas a negative relation has been reported between irrigation amounts and polyphenol content (Patumi et al.,1999; Gómez-Rico et al., 2007). On the other hand, it has been shown that irrigation also affects the phenolic and the volatile profiles, which is cultivar dependent (Romero et al., 2002). Thus, it is very relevant to highlight that any type of irrigation management employed in olive orchards must take into account the compromise between the effect on olive oil yield and on VOO quality, especially in relation to minor compounds, as they are the main determinants of oxidative stability and for their exceptional flavour (Tovar et al., 2001; GómezAlonso et al., 2002; Guerfel et al., 2012).

The aim of this study was to evaluate the effect of different irrigation strategies in VOO saponifiable and unsaponifiable composition and $\mathrm{VOO}$ quality of a Portuguese cultivar, cv. Cobrançosa, integrated in a protected denomination of origin (PDO) of "Azeite de Trás-os-Montes" in the Northeast of Portugal.

\section{MATERIALS AND METHODS}

\subsection{Study site and experimental conditions.}

The experiment was conducted during 2005 and 2006, in a 10-year-old commercial olive (Olea europaea L. cv "Cobrançosa") orchard, with a tree spacing of $6 \mathrm{~m} \times 6 \mathrm{~m}$, located at Vilariça Valley $\left(41.33^{\circ} \mathrm{N}, 7.04^{\circ} \mathrm{W} ; 240 \mathrm{~m}\right.$ altitude) a typical olive growing area of Northeast of Portugal. Three irrigation treatments were applied: full irrigation (T2) that received a seasonal water equivalent to $100 \%$ of estimated crop evapotranspiration $\left(E T_{c}\right)$, continuous deficit irrigation (T1) that received a volume of water equivalent to $30 \%$ of estimated $\mathrm{ET}_{\mathrm{c}}$ and a rainfed treatment (T0). The trees were dripirrigated daily by 4 drippers per tree (two at $0.5 \mathrm{~m}$ and two at $1.5 \mathrm{~m}$ from the trunk), each with a flow rate of $4 \mathrm{~L} \mathrm{~h}^{-1}$, connected to a single drip line. The experimental layout consisted of three adjacent blocks each of these made of four rows with twenty olives trees, where only the six central trees were used for sampling. Additional information about climatic conditions, amount of water applied, irrigation water quality and soil properties may be found in Fernandes-Silva et al. (2010).

In order to express the effect of the different irrigation regimes used and the water status, the water stress integral (S $\psi)$ as defined by Myers (1988) was calculated from the midday shoot water potential $(\Psi)$ data in both years from DOY 167-273:

$$
\mathrm{S} \psi=\left|\Sigma\left(\mathrm{S}_{\mathrm{m}}-\mathrm{c}\right) \mathrm{n}\right|
$$

Where $S_{m}$ is the average of shoot water potential for any interval, $c$ is the maximum shoot water potential and $n$ is the number of the days in the interval. Detailed information about the measurement of shoot water potential has been reported in a previous work (Fernandes-Silva et al., 2010).

\subsection{Yield and olive oil samples}

Harvest was performed in the first half of December each year. Each tree was manually harvested and the yield weighed at the site. The olive ripeness index was determined immediately before harvest, a sample of 100 fruits/tree were randomly collected around the canopy of the tree and three replications per treatment were sampled; the fruits were classified using a 0 to 7 scale according to skin color (Beltran et al., 2008). Subsamples of around $3 \mathrm{~kg}$ of each tree/treatment were collected and mixed to complete a sample of $18 \mathrm{~kg}$ which was used for VOO extraction by the system Oliomio (Oliomio 50) hammer mild. The paste underwent malaxation at $25^{\circ} \mathrm{C}$ for $30 \mathrm{~min}$ and the oil extracted with a two-phase decanter.

\subsection{Analytical determinations}

All analytical determinations were carried out in triplicate. The free acidity, given as \% of oleic acid, 
peroxide value $(\mathrm{PV})$, expressed as meq of active oxygen per $\mathrm{kg}$ of oil $\left(\mathrm{meqO}_{2} / \mathrm{kg}\right), \mathrm{K}_{232}$ and $\mathrm{K}_{270}$ extinction coefficients calculated from absorption at 232 and $270 \mathrm{~nm}$, totals sterols and fatty acid composition were quantified following the analytical methods in accordance with the European Official Methods (UE 1989/2003 modifying the ECC 2568/91).

\subsection{Polyphenol content}

Phenolic compounds were isolated and extracted using the modified method described by (VázquezRoncero et al., 1973). The oil sample (10 g) dissolved in $\mathrm{n}$-hexane $(25 \mathrm{~mL})$, was extracted $(10 \mathrm{~mL})$ in triplicate with methanol/water (60:40). The aqueous fractions were collected in a volumetric flask $(50 \mathrm{~mL})$ and completed with distilled water to obtain the total polyphenol extract. The concentration of total polyphenol was estimated with the FolinCiocalteau reagent at $725 \mathrm{~nm}$. Results were expressed as mg of caffeic acid per $\mathrm{kg}$ of oil.

\subsection{Tocopherols}

An oil sample of $1 \mathrm{~g}$ was dissolved in $10 \mathrm{~mL}$ of acetone and $\alpha$-tocopherol and $\gamma$-tocopherol were determined by HPLC equipped with a photodiode detector UV set at $292 \mathrm{~nm}$. The column used was a Lichrospher $100 \mathrm{RP}_{18} 5 \mu \mathrm{m} \times 25 \mathrm{~cm}$ (Merck) under isocratic conditions, with acetronitrile + methanol $(1: 1 \mathrm{v} / \mathrm{v}) /$ phosphoric acid $(96: 4 \mathrm{v} / \mathrm{v})$ as the mobile phase at a flow rate of $2 \mathrm{~mL} / \mathrm{min}$; the injection volume was $20 \mu \mathrm{L}$.

\subsection{Oxidative Stability}

This was measured by the Rancimat method (Laübli \& Bruttel, 1986). Oxidative stability is expressed as the induction time (hours) measured with the Rancimat apparatus (Metrohm, Switzerland) using an oil sample of $4 \mathrm{~mL}$ at $110^{\circ} \mathrm{C}$ and $20 \mathrm{~L} \mathrm{~h}^{-1}$ air flow. The time taken to reach a fixed level of conductivity was measured.

\subsection{Sensory analysis}

Sensory analysis is evaluated by quantitative descriptive analysis (QDA), which was made by a Panel test, all elements of staff of the Technical Studies Laboratory at Institute of Agronomy, Technical University of Lisbon, according to current UE regulation (UE 1989/2003 modifying the ECC 2568/91). The evaluators had experience in QDA and in virgin olive oil sensory evaluation; they are recognized by the International Olive Council. The samples of VOO (15 g), in duplicate, were provided to the evaluators in blue glass tumblers $(100 \mathrm{~mL})$, covered with watch glasses and heated at approximately $20^{\circ} \mathrm{C}$, in a heater device. For a description of the $\mathrm{VOO}$, the following terms were used: olive fruity; apple; other fruits like almonds and nuts; and negative attributes for the VOO olfactory profile; bitter, pungent, sweet, cut grass and negative attributes to define the VOO taste notes.

\subsection{Statistical analysis}

Results are shown as figures and tables using Microsoft Excel. Correlation analysis (Pearson's correlation) was performed with Statistica for Windows release 7.0 .

\section{RESULTS AND DISCUSSION}

\subsection{Water status and oil yield}

Irrigation treatments clearly affected tree water status. At the end of the growing season water stress integral values of rainfed (TO) and continuous deficit irrigation (T1) were 8.0 and 2.3 times greater than full irrigated tress (T2), respectively, in 2005, and 8.7 and 3.2 , respectively in 2006 (Table 1). The plants of the rainfed treatment experienced a severe water deficit, with values of midday and predawn stem water potential lower than $-7 \mathrm{MPa}$ as reported in a previous work (Fernandes-Silva et

Table 1

Water status in Cobrançosa olive trees, normalized oil yield and maturation indices in 2005 and $2006(n=6)$. T0-Rainfed, T1 and T2 = irrigated with $30 \%$ and $100 \% \mathrm{ET}_{c}$, respectively

\begin{tabular}{ccccc}
\hline Year & $\begin{array}{c}\text { Irrigation } \\
\text { level }\end{array}$ & $\begin{array}{c}\text { Water stress: } \\
\text { DOY167-273 integral } \\
\left(\mathbf{S} \psi_{167-273}, \mathbf{M P a} \times \text { day) }\right.\end{array}$ & $\begin{array}{c}\text { Oil yield/TCSA } \\
\left(\mathbf{g ~ m}^{-2}\right)\end{array}$ & $\begin{array}{c}\text { Maturation } \\
\text { indices }\end{array}$ \\
\hline \multirow{2}{*}{2005} & T2 & $36.2 \pm 22.9$ & $149.2 \pm 31.8$ & $3.07 \pm 0.04$ \\
& T1 & $82.3 \pm 31.6$ & $92.1 \pm 39.0$ & $3.26 \pm 0.03$ \\
& T0 & $290.0 \pm 35.5$ & $29.0 \pm 31.6$ & $3.81 \pm 0.02$ \\
& T2 & $23.2 \pm 8.1$ & $178.7 \pm 31.5$ & $3.27 \pm 0.03$ \\
& T1 & $73.4 \pm 12.1$ & $173.7 \pm 9.10$ & $3.36 \pm 0.02$ \\
& T0 & $201.2 \pm 14.9$ & $116.1 \pm 23.2$ & $3.74 \pm 0.01$ \\
\hline
\end{tabular}

TCSA -trunk cross sectional area oil yield- Total virgin olive oil physically extracted. 
al., 2010), while in T2 those values never fell below -2.5 and $-0.70 \mathrm{MPa}$, respectively.

The improvement of tree water status with irrigation had a positive effect on growth, which was reflected in an increase of trunk diameter of irrigated treatments with higher values in T2. The results about trunk diameter, olive production, fruit size, dry matter and olive oil physically extracted are published in a previous work (FernandesSilva et al., 2010). Because trunk diameter were distinct between irrigation treatment as shown in Fernandes-Silva et al. (2010), so we used the parameter oil yield/TCSA (trunk cross sectional area) to express the results of olive oil production. Thus, oil yield/TCSA of T1 and T0 treatments was 81 and $44 \%$ of that of T2 trees, respectively (means of both growing seasons). Hence, deficit irrigation produced a slight reduction in oil yield $(19 \%)$ while saving about $1200 \mathrm{~m}^{-3}$ ha of applied water per year (Fernandes-Silva et al., 2010), confirming results obtained with other olive cultivars (Motilva et al., 2000; Gucci et al., 2007). In both years the maturation indices at the ripening data was lower in fully irrigated trees, whereas they showed the highest values in rainfed trees. This can be explained by the higher crop load of the trees in the irrigated treatments that retard fruit maturation and anthocyanin accumulation. In fact, several studies have shown that a low crop load hastens and shortens fruit ripening (Barone et al., 1994).

\subsection{Virgin olive oil quality indices}

The effect of irrigation level in Cobrançosa oil sample quality indices are shown in Table 2. The values of free acidity, peroxide value and absorptions characteristic in the UV region at 270 $\mathrm{nm}$ and $232 \mathrm{~nm}$ for all olive oil samples studied were lower than the maximum limits imposed for the EU legislation (UE 1989/2003 modifying the
ECC 2568/91) for the extra virgin olive oil category. Free acidity showed a more marked difference between the two years than among irrigation treatments. Thus, the higher values were observed in 2005 in T0 treatment while the lower was in T2; whereas in 2006 the difference between treatments was slight. The higher values observed in 2005 may be explained with fruit damage caused by olive fly (Bactrocera olea Gmelin) attacks. This was also observed by Gomez-Rico et al. (2007) in virgin olive oils from cv. Cornicabra. Peroxide value (Table 2) showed a tendency to increase with irrigation level, which is consistent with previous studies (Ismail et al., 1999; Stefanoudaki et al., 2009), while others reported no differences with irrigation level (Patumi et al., 1999; Faci et al., 2002; Gómez-Rico et al., 2009). In the 2005 season, this parameter was $50 \%$ higher in watered treatments (T1 and T2) than in the T0 treatment, whereas in 2006 it was only $12.5 \%$ and $38 \%$ higher for $\mathrm{T} 1$ and $\mathrm{T} 2$, respectively. Spectrophotometric absorbance characteristics in the UV region at $232 \mathrm{~nm}$ and $270 \mathrm{~nm}$ did not show a clear response to irrigation in the two years of study. In 2005, the presence of conjugated diene content (as indicated by $\mathrm{K}_{232}$ ) was the same in $\mathrm{T} 2$ and $\mathrm{T} 0$, while in T1 this parameter increased 6\%; in 2006 the differences between treatments were very small $(\leq 2 \%)$. Although, the effect of irrigation on these parameters is not sufficiently documented, there are studies with conflicting results. For example, several studies (Ismail et al., 1999; Gómez-Rico et al., 2007; Aganchich et al., 2008) reported that theses indices decreased with irrigation amounts while others reported no effect (Stefanoudaki et al., 2001). Gómez-Rico et al. (2007) attribute this effect to the interference of phenolic compounds content (higher in rainfed), which absorbs in the UV region in these analytical determinations.

It has been recognized that polyphenols and tocopherols are substances with natural antioxidant properties and their presence in olive oils has

Table 2

Values of acidity, peroxide value, K232 and K270 extinction coefficients, Total polyphenols and oxidative stability of cv. Cobrançosa virgin olive from diferrent irrigation regimes in 2005 and 2006. T0-Rainfed, T1 and T2 = irrigated with $30 \%$ and $100 \%$ ETc, respectively

\begin{tabular}{ccccccc}
\hline $\begin{array}{c}\text { Irrigation } \\
\text { level }\end{array}$ & $\begin{array}{c}\text { Free acidity } \\
(\%)\end{array}$ & $\begin{array}{c}\text { Peroxide value } \\
\left(\mathbf{m e q} . \mathbf{O}_{\mathbf{2}} \mathbf{~ k g}^{-1}\right)\end{array}$ & $\mathbf{K}_{232}$ & $\mathbf{K}_{270}$ & $\begin{array}{c}\text { Total } \\
\text { Polyphenols } \\
\left(\mathbf{m g ~ k g}^{-1}\right)\end{array}$ & $\begin{array}{c}\text { Oxidative } \\
\text { stability (h) }\end{array}$ \\
\hline 2005 & & & & & & \\
T2 & $0.55 \pm 0.02$ & $10.33 \pm 0.58$ & $1.86 \pm 0.00$ & $0.12 \pm 0.00$ & $100.37 \pm 1.50$ & $11.93 \pm 0.06$ \\
T1 & $0.60 \pm 0.01$ & $10.00 \pm 0.00$ & $1.95 \pm 0.00$ & $0.12 \pm 0.00$ & $181.87 \pm 1.10$ & $13.33 \pm 0.06$ \\
T0 & $0.81 \pm 0.02$ & $6.67 \pm 0.58$ & $1.85 \pm 0.01$ & $0.13 \pm 0.00$ & $274.03 \pm 2.20$ & $17.50 \pm 0.17$ \\
2006 & & & & & & \\
T2 & $0.30 \pm 0.00$ & $11.00 \pm 0.02$ & $1.81 \pm 0.02$ & $0.10 \pm 0.01$ & $155.00 \pm 0.31$ & $12.40 \pm 0.15$ \\
T1 & $0.20 \pm 0.00$ & $9.00 \pm 0.01$ & $1.83 \pm 0.05$ & $0.11 \pm 0.02$ & $237.00 \pm 3.26$ & $15.70 \pm 0.10$ \\
T0 & $0.20 \pm 0.00$ & $8.00 \pm 0.00$ & $1.79 \pm 0.01$ & $0.11 \pm 0.00$ & $206.20 \pm 2.08$ & $17.70 \pm 0.15$ \\
\hline
\end{tabular}

values $\pm \mathrm{SD}$ of three determinations. 
been associated to their general quality, improving stability, nutritional value and sensorial properties (Boskou et al., 2006). In this study full irrigation (T2) revealed a tendency to decrease the concentrations of total polyphenols (TP), which may range from $25-51 \%$ and $31-45 \%$ in relation with rainfed (T0) and deficit irrigation (T1), respectively (Table 2 ), which corroborate with observed by other authors (Tovar et al., 2001; Patumi et al., 2002; d'Andria et al., 2004; Moriana et al., 2007) in other cultivars. Although, within the same cultivar, polyphenol contents may vary widely according to ripening stage, climate and agronomic factors, the values of TP found in this particular study were in the range of previous work with cv. Cobrançosa (Matos et al., 2007a). A good linear relationship was observed between total polyphenols and water stress integral (Table 3), which is in accordance with previous reports (Owen et al., 2000; Servilli, et al., 2007). Therefore, olive trees that had been exposed to a certain level of water deficit produced oils with higher concentrations of polyphenols, which were seemingly richer in the olive fruit (Patumi et al., 1999; Tovar et al., 2002). In addition, previous studies in cv. Cornicabra (Moriana et al., 2007) indicated that the effect of water status of olive trees throughout the year affects the concentration of phenolics and not just during the oil accumulation. These authors found that the total phenol content of the rainfed trees was sharply reduced in years which had a rainy spring (the last rain falling in June) and a dry autumn.

Table 4 reports the content of $\alpha$ and $\gamma$-tocopherols from the tree irrigation regimes. In 2005 , it is possible to observe a decreasing trend in $\gamma$-tocopherol with the amount of water applied, from $14 \%$ to $22 \%$ in T1 and T2 treatments, respectively, to T0, whereas $\gamma$-tocopherol did not reveal a clear behavior, with slight differences between treatments $(\leq 5 \%)$. In 2006 , these parameters showed an opposite behavior in relation to 2005 . The values found in this study were in the range observed in a previous work for this cultivar (Matos et al., 2007b).

VOO obtained from the T0 treatment showed the highest resistance to oxidation, as a result of the highest values observed (17.5 to $17.7 \mathrm{~h}$ ) of oxidative stability (Table 2). This parameter was reduced by $30 \%$ and $11-22 \%$ in $\mathrm{T} 2$ and $\mathrm{T} 1$, respectively. This decrease in oxidative stability is usually explained by the decrease in natural antioxidants like polyphenols, tocopherols. Given this assumption, several researchers have tried to find which of the mentioned substances is

Table 3

Correlation between polyphenols and tocopherols contents and water stress integral and correlation between polyphenols and tocopherols contents and oxidative stability of cv. Cobrançosa, virgin olive oils extracted from olives with different irrigation regimes $(n=6)$

\begin{tabular}{lcc}
\hline & \multicolumn{1}{c}{ Polyphenols } & Tocopherols \\
\hline Water stress integral $^{\mathrm{a}}$ & $y=0.473 x+133.371$ & $y=0.121 x+271.188$ \\
& $r^{2}=0.715 ; p=0.033$ & $r^{2}=0.200 ; p=0.373$ \\
Oxidative stability $^{\mathrm{b}}$ & $y=0.038 x+7.678$ & $y=0.046 x+1.571$ \\
& $r^{2}=0.747 ; p=0.026$ & $r^{2}=0.24 ; p=0.322$ \\
\hline
\end{tabular}

${ }^{\mathrm{a}}$ variable predictor; ${ }^{\mathrm{b}}$ variable dependent.

Table 4

Sterol and tocopherol composition of cv. Cobrançosa virgin olive from different irrigation regimes in 2005 and 2006. T0-Rainfed, T1 and T2 = irrigated with $30 \%$ and $100 \%$ ETc, respectively

\begin{tabular}{|c|c|c|c|c|c|c|c|c|}
\hline \multirow{2}{*}{$\begin{array}{c}\text { Irrigation } \\
\text { Level/ } \\
\text { Year }\end{array}$} & \multicolumn{5}{|c|}{ Sterol Parameter $\left(\mathrm{mg} \mathrm{kg}^{-1}\right)$} & \multirow[b]{2}{*}{ Total } & \multicolumn{2}{|c|}{ Tocopherols (mg kg-1) } \\
\hline & Cholesterol & Campesterol & Stigmasterol & $\beta$-Sitosterol & $\Delta$-Stigmasterol & & $\alpha$ & $\gamma$ \\
\hline \multicolumn{9}{|l|}{2005} \\
\hline T2 & $1.5 \pm 0.0$ & $41.8 \pm 0.42$ & $17.9 \pm 0.2$ & $1418.9 \pm 13.8$ & $3.0 \pm 0.0$ & $1491 \pm 15.1$ & $225.1 \pm 5.0$ & $17.5 \pm 0.5$ \\
\hline $\mathrm{T} 1$ & $2.8 \pm 0.0$ & $37.5 \pm 0.63$ & $13.0 \pm 0.9$ & $1327.5 \pm 18.6$ & $2.8 \pm 0.0$ & $1393 \pm 19.5$ & $248.0 \pm 3.0$ & $16.1 \pm 0.2$ \\
\hline TO & $1.8 \pm 0.0$ & $45.6 \pm 0.98$ & $9.4 \pm 1.1$ & $1681.5 \pm 37.4$ & $3.5 \pm 0.1$ & $1753 \pm 37.5$ & $287.1 \pm 2.1$ & $17.0 \pm 0.2$ \\
\hline \multicolumn{9}{|l|}{2006} \\
\hline T2 & $1.7 \pm 0.0$ & $45.7 \pm 1.4$ & $14.9 \pm 0.1$ & $1577.0 \pm 17.0$ & $3.3 \pm 0.0$ & $1653 \pm 16.1$ & $320.0 \pm 4.5$ & $14.8 \pm 0.5$ \\
\hline $\mathrm{T} 1$ & $1.6 \pm 0.0$ & $42.1 \pm 0.6$ & $11.1 \pm 0.1$ & $1510.9 \pm 11.9$ & $3.2 \pm 0.0$ & $1580 \pm 11.7$ & $279.9 \pm 6.0$ & $14.0 \pm 0.5$ \\
\hline TO & $1.7 \pm 0.0$ & $48.8 \pm 0.7$ & $8.6 \pm 0.1$ & $1651.0 \pm 21.5$ & $3.5 \pm 0.0$ & $1724 \pm 21.6$ & $281.4 \pm 1.0$ & $16.8 \pm 0.3$ \\
\hline
\end{tabular}

values \pm SD of tree determinations. 
more correlated with oxidative stability. A number of studies have demonstrated that polyphenols contents are, among the minor compounds, the group more correlated with this parameter (Salvador et al., 1999; Gómez-Alonso et al., 2002; Matos et al., 2007a). In our study, a high correlation was verified between polyphenol contents and oxidative stability (Table 3). Pearson's correlation coefficients between these variables was high and significant $(p=0.026)$ but not significant correlation was found between oxidative stability and tocopherols content $(p=0.322)$, which is in agreement with previous studies (Baldioli et al., 1996; Stefanoudaki et al., 2009). The antioxidant behaviour of tocopherols represents a complicated phenomenon as they are efficient antioxidants at low concentrations but they steadily lose efficiency as their content in the vegetables oils increase (Kamal-Eldin, 2006). Indeed, studies on the contribution of different compounds in virgin olive oil stability reported that the oleic/linoleic acid ratio was one of the main determinants of oxidative stability (Aparicio et al., 1999). It is well-known that polyunsaturated fatty acids are more susceptible to oxidation, and consequently, could shorten the shelf life of the oil. Furthermore, olive oil oxidative stability might depend on some synergistic effects (still unknown) among fatty acid composition, phenolic compounds, tocopherols, carotenoids and chlorophylls (Aparicio et al., 1999).

Sterol content decreased in irrigated treatments (Table 4), due to the decrease in $\gamma$-sistosterol, the main sterol, which was more pronounced in 2005 . These results agreed with previous previous results in cv Koroneiki (Stefanoudaki et al., 2009) and were in contrast with those reported in cv. Arbequina (Faci et al., 2002), which indicated a lack of response of these compounds with increasing applied water. In our study we observed an opposite trend for the stigmasterol fraction, with increases from $80 \%$ (T1) to $140 \%$ (T2), while the other sterols (cholesterol, campesterol and $\gamma$-stigmasterol) did not show important variations.

\subsection{Virgin olive oil major components: fatty acid composition}

Table 5 shows the fatty acid composition of the VOO from the tree irrigations regimes, which is typical of this cultivar (Matos et al., 2007b). The results reveal a variation in behavior of fatty acid composition between years in response to irrigation. In 2005 full irrigation showed the highest content in oleic acid (18:1), and the lowest in linoleic acid (18:2), while in 2006 we found an opposite behavior, with the highest values of $18: 1$ and the lowest of 18:2 in the rainfed treatment. However, in both years, differences in 18:1 between treatments were very small $(\leq 2 \%)$, while those in 18:2 were more pronounced (12-14\%). In relation to palmitic acid (16:0), in 2005, the concentration did not change with irrigation, while in 2006 there was an increase with the water applied. Additionally, regardless of the irrigation regime, the highest values of 18:1 corresponded to the lowest of 18:2. In fact, it has been reported that the contents of 18:1 and palmitic acid (16:0) decreases during ripening, while that of $18: 2$ acid increases due to the transformation of $18: 1$ into $18: 2$ acid by the oleate desaturase activity, which is active during triacylglycerol biosynthesis (Nergiz and Engez, 2000). The variable behavior between years, and sometimes opposite, verified in the main fatty acid of olive oil (oleic, linoleic and palmitic) in response to water regime observed in this study agrees with the results found in other cultivars. For example, Gómez-Rico et al. (2007) in cv. "Cornicabra" observed, in a given year, a significantly higher content of 18:1 acid in olive oil from dry conditions, whereas in irrigated trees they found significantly higher content of 16:0 acid and 18:2 acid, and in the following year these differences were not

Table 5

Fatty acid composition (\%) of cv. Cobrançosa virgin olive from different irrigation regimes in 2005 and 2006. T0-Rainfed, T1 and T2 = irrigated with $30 \%$ and $100 \%$ ETc, respectively

\begin{tabular}{ccccccccccc}
\hline $\begin{array}{c}\text { Irrigation } \\
\text { level }\end{array}$ & $\mathbf{C 1 6 : 0}$ & $\mathbf{C 1 6 : 1}$ & $\mathbf{C 1 7 : 0}$ & $\mathbf{C 1 7 : 1}$ & $\mathbf{C 1 8 : 0}$ & $\mathbf{C 1 8 : 1}$ & $\mathbf{C 1 8 : 2}$ & $\mathbf{C 1 8 : 3}$ & $\begin{array}{c}\text { Uns/ } \\
\text { Sat }\end{array}$ & $\begin{array}{c}\text { Mono/ } \\
\text { Poly }\end{array}$ \\
\hline 2005 & & & & & & & & & & \\
T2 & $11.7 \pm 0.0$ & $0.9 \pm 0.0$ & $0.1 \pm 0.0$ & $0.2 \pm 0.0$ & $4.0 \pm 0.0$ & $73.6 \pm 0.0$ & $7.8 \pm 0.0$ & $0.9 \pm 0.0$ & 5.0 & 8.6 \\
T1 & $11.8 \pm 0.0$ & $0.9 \pm 0.0$ & $0.1 \pm 0.0$ & $0.2 \pm 0.0$ & $4.5 \pm 0.0$ & $72.1 \pm 0.0$ & $8.8 \pm 0.0$ & $0.8 \pm 0.0$ & 4.8 & 7.7 \\
T0 & $11.6 \pm 0.0$ & $0.9 \pm 0.0$ & $0.2 \pm 0.0$ & $0.3 \pm 0.0$ & $4.0 \pm 0.0$ & $72.3 \pm 0.0$ & $9.1 \pm 0.0$ & $0.8 \pm 0.0$ & 5.0 & 7.4 \\
2006 & & & & & & & & & & \\
T2 & $11.9 \pm 0.1$ & $1.0 \pm 0.0$ & $0.1 \pm 0.0$ & $0.2 \pm 0.06$ & $4.4 \pm 0.0$ & $70.3 \pm 0.0$ & $10.2 \pm 0.0$ & $1.0 \pm 0.0$ & 4.7 & 6.4 \\
T1 & $12.3 \pm 0.1$ & $1.0 \pm 0.1$ & $0.2 \pm 0.1$ & $0.2 \pm 0.00$ & $5.0 \pm 0.0$ & $69.7 \pm 0.3$ & $9.8 \pm 0.1$ & $0.9 \pm 0.0$ & 4.4 & 6.6 \\
T0 & $11.4 \pm 0.2$ & $1.2 \pm 0.1$ & $0.1 \pm 0.0$ & $0.2 \pm 0.00$ & $4.1 \pm 0.0$ & $71.2 \pm 0.2$ & $9.1 \pm 0.1$ & $0.9 \pm 0.0$ & 4.7 & 7.3 \\
\hline
\end{tabular}

Saturated acids: C16:0 palmitic, C17:0 heptadecanoic, C18:0 stearic; unsaturated acids: C16:1 palmitoleic, C17:1 heptadecenoic, C18:1 oleic, C18:2 linoleic, C18:3 linolenic eicosanoic; Uns/Sat = unsaturated saturated acids ratios; Mono/Poly = monounsaturated polyunsaturated acids ratios. Values \pm SD of tree determinations. 
observed. Similarly, other studies reported no differences among water regimes (Patumi et. al., 1999; Motilva et. at., 2000; Patumi et al., 2002). For example, Magliulo et al. (2003) reported that olive oil fatty acid composition from two different cultivars ("Frantoio" and "Leccino") was more affect by varietal factors and climatic conditions of the year than by water regimes. They also found that during the maturation of olive fruits, the occurrence of high temperatures early in the triacylglycerol biosynthesis reduced $18: 1$ acid content whereas 16:0 acid increased in cv. "Leccinio", while in cv. "Frantoio", that was not observed, indicating that it is related to the different response of the cultivar to environmental conditions. In addition, Rondanini et al. (2011) observed that the Spanish cultivar "Arbequina", when cultivated in warm arid valleys of Northwestern Argentina (La Rioja), produced a lower content of $18: 1$ acid in relation to the Mediterranean region. They founded a decrease with increasing temperature during oil accumulation of $2 \%$ per ${ }^{\circ} \mathrm{C}$. Taken together, these data indicate that there are strong varietal differences in the response of olive oil quality to water stress that may reflect the balance of enzymes used for fatty acid biosynthesis.

Changes in the ratio of unsaturated/saturated fatty acids affect organoleptic properties of olive oil, as oil with a high content of saturated fatty acids is more viscous and remains longer in contact with mucous membranes of the oral cavity, giving rise to the "fatty" defect (d'Andria et al., 2004). Besides, the variation of the ratio monounsaturated/ polyunsaturated fatty acids may affect the oil shelf lives. The effect of fatty acids on stability depends mainly on their degree of unsaturation and, to a lesser degree, on the position of the unsaturated functions within the triacylglycerol molecule (Kamal-Eldin, 2006). In our study, no differences were observed in the relationship unsaturated/ saturated fatty acids (Uns/Sat) between TO and $\mathrm{T} 2$, while $\mathrm{T} 1$ had $6 \%$ lower values than the other treatments (Table 5), as a result of the higher content of saturated fatty acids (especially 16:0) in this treatment. Conversely, the relationship Mono/Poly showed a tendency of variation with the water regime, which was variable according to the year, in agreement with the inter-annual variations observed for $18: 1$ and 18:2 fatty acids. These observations contrast with the results of Gómez-Rico et al. (2007) who found that Uns/Sat and Mono/Poly were significantly higher in olive oil from rainfed conditions, although the difference was small and thus of no nutritional significance. In opposition, other studies have shown that these relations are not affected by irrigation (Patumi et al., 2002; d'Andria et al., 2004).

\subsection{Sensory Analysis}

Figure 1 shows the sensory profile for olive oils from the three irrigation treatments. In both years, the characteristic pungent and bitter are
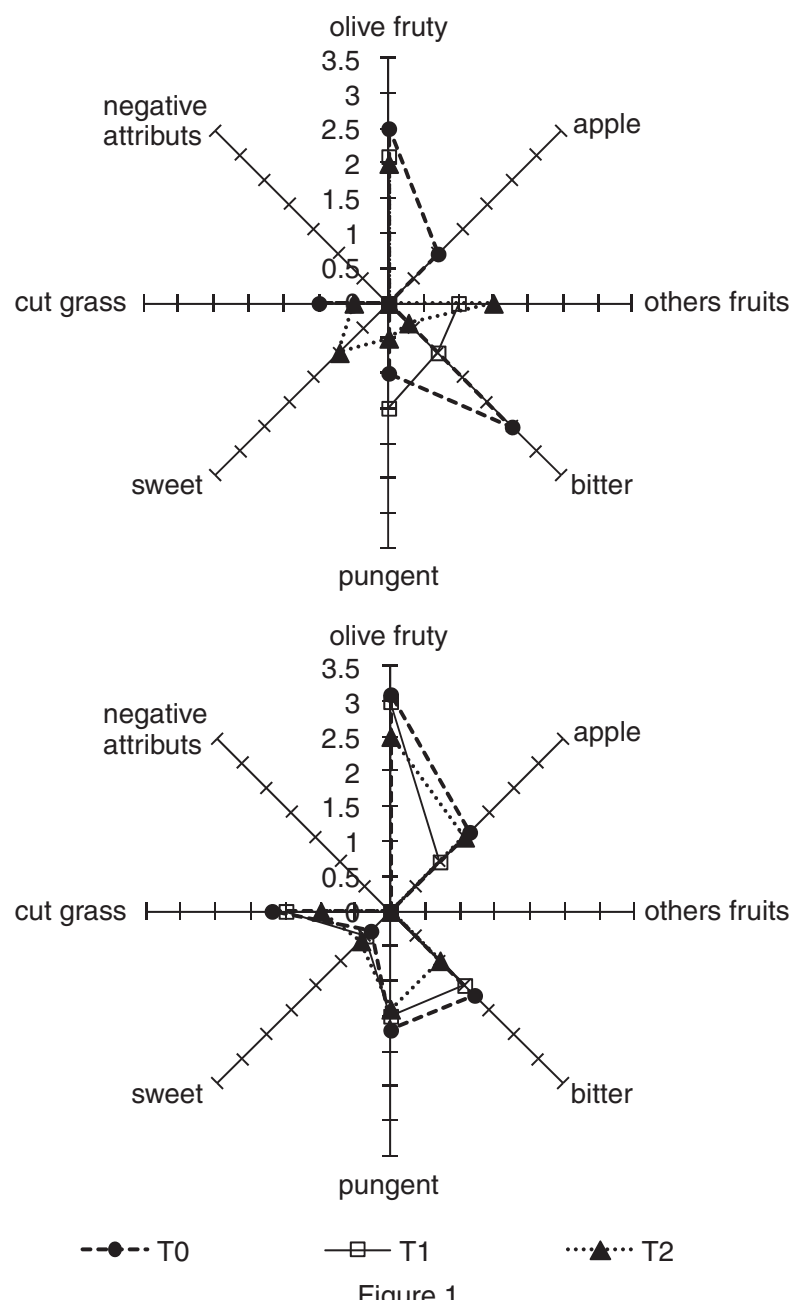

Sensory profile of virgin olive oils from cv. Cobrançosa from different irrigation regimes in 2005 (A) and 2006 (B).

T0-Rainfed, T1 and T2 = irrigated with $30 \%$ and $100 \%$ ETC, respectively.

more pronounced in olive oils from T0 and T1, which had higher polyphenolic concentrations. This relationship is more prominent in 2005, the year with the higher stress level (Table 1). In general, it is possible to note that the olive oil from cv. Cobrançosa is more bitter than pungent. The other notes perceived in the $\mathrm{VOO}$ of this cultivar are olive fruity, which seems invariable with irrigation, other fruits, like almond, nuts, which are typical of this cultivar (Gouveia, 1995) and are only perceived in 2005, the driest year. The perception of apple in 2005 is only present in T0, whereas in 2006 it is present in all olive oils from the three treatments, with the lower note in T1. All virgin olive oils obtained using the different irrigations treatments were classified as extra virgin by mean of the organoleptic evaluation carried out by a recognized olive oil panel test.

\subsection{Conclusions}

The VOO quality parameters that appear to be influenced by irrigation in cv. Cobrançosa were peroxide value, totals polyphenols, oxidative stability 
and sensory characteristics. The other quality parameters like spectrophotometric absorbance in UV region (232 and $270 \mathrm{~nm}$ ) and total tocopherols showed a behavior not consistent with the amount of water applied in the two years. Regarding to the fatty acid composition the results indicated that the small variations observed are due to inter annual variations of climatic conditions prevailing at the time of the biosynthesis of triglyceride rather than to the effect of irrigation. The sensory attributes pungent and bitter are more pronounced in olive oils from rainfed and deficit irrigation, which had higher polyphenolic concentrations. In general, the olive oil from cv. Cobrançosa is more bitter than pungent.

A strategy of continuous deficit irrigation with only $30 \%$ of maximum $\mathrm{ET}_{\mathrm{c}}$ may have an advantageous effect, as it increased oil yield to more than double that of rainfed conditions while VOO quality was similar. However, the preliminary results of this work suggest that a study of other deficit irrigation strategies is still required for cv. "Cobrançosa" to refine the adoption of an efficient irrigation strategy in situations where full irrigation supply is not viable, take into account the compromise between the effect on olive oil yield and on VOO quality, especially in relation to minor compounds.

\section{ACKNOWLEDGEMENTS}

This study was supported by project AGRO 175 of AGRO-INIA program of Ministério da Agricultura (Portugal) and Fundação para a Ciência e a Tecnologia do Ministério da Ciência, Tecnologia e do Ensino Superior (Portugal) which supported a PhD grant (SFRH/BD/18441/2004). The authors are very grateful to Eng. Manuel Afonso for providing the experimental orchard.

\section{REFERENCES}

Aganchich B, El Antari A, Wahbi S, Tahi H, Wakrim R, Serraj R. 2008. Fruit and oil quality of mature olive trees under partial rootzone drying in field conditions. Grasas Aceites 59, 225-233.

Aparicio R, Roda L, Albi MA, Gutiérrez F. 1999. Effect of various compounds on virgin olive oil stability measured by rancimat. J. Agric. Food Chem. 47, 4150-4155.

Baldioli M, Servili M, Perrett G, Montedoro GF. 1996. Antioxidant activity of tocopherols and phenolic compounds of virgin olive oil. J. Am. Oil Chem. Soc. 73, 1589-1593.

Barone E, Gullo G, Zappia R, Inglese P. 1994. Effect of crop load on fruit ripening and olive oil (Olea europea L.) quality. J. Hort. Sci. 69, 67-73.

Beltran G, Uceda M, Hermoso M, Frias LM. 2008. Maduración, In: Barranco D, Fernández-Escobar R, Rallo L (Eds). El cultivo del olivo, Mundi-Prensa, Madrid, pp 163-187.

Bonoli M, Bendini A, Cerretani L, Lercker G, Gallina T. 2004. Qualitative and semiquantitative analysis of phenolic compounds in extra virgin olive oils as a function of the ripening degree of olive fruits by different analytical techniques. J. Agric. Food Chem. 52, 7026-7032.

Boskou D, Tsimidou M, Blekas G.2006. Polar Phenolic Compounds: In D. Boskou (Ed.). Oil Chemistry and Technology, Champaign: AOCS Press, pp.41-67.

d'Andria R, Lavini A, Morelli G, Patumi M, Terenziani S, Calandrelli D, d Fragnito F. 2004. Effects of water regimes on five pickling and double aptitude olive cultivars (Olea europaea L.). J. Hort. Sci. Biotechnol. 79, 18-25.

European Union Commission Regulation. 2003. Council Regulation (EC) No 1989/2003 of 21 October 2003, amending Regulation No 2568/91 EEC on the characteristics of olive oil and olive-pomace oil and on the relevant methods of analysis modifies the No. 2568/91 EEC on olive oils and pomace olive oils characteristics and relative analysis methods. E.U. Off. J. Eur. Communities, L. 295, 57-56.

Faci JM, Berenguer MJ, Espada, JL, Gracia S. 2002. Effect of variable water irrigation supply in olive (Olea europaea L.) cv. Arbequina in Aragon (Spain). II. Extra Virgin oil quality parameters. Acta Hortic. 586, 649-652.

Fernandes-Silva AA, Ferreira TC, Correia, CM, Malheiro, AC, Villalobos FJ.2010. Influence of different irrigation regimes on crop yield and water use efficiency of olive. Plant Soil 333, 35-47.

Gómez-Alonso S, Salvador MD, Fregapane G. 2002. Phenolic compounds profile of Cornicabra virgin olive oil J. Agric. Food Chem. 50, 6812-6817.

Gómez-RicoA, Salvador MD, Moriana A, Pérez D, Olmedilla N, Ribas F, Fregapane G. 2007. Influence of different irrigation strategies in a tradicional Cornicabra cv. olive orchard on virgen olive oil composition and quality. Food Chem. 100, 568-578.

Gómez-Rico A, Salvador MD, Fregapane G. 2009. Virgin olive oil and olive fruit minor constituents as affected by irrigation management based on SWP and TDF as compared to ETc in medium-density young olive orchards (Olea europaea L. Cv. Cornicabra and Morisca). Food Res. Int. 42, 1067-1076.

Gouveia JMB. 1995. Azeites Virgens do Alto Alentejo: Comportamentos químico, tecnológico e sensorial. PhD. Universidade Técnica de Lisboa, Instituto Superior de Agronomia, Lisboa, Portugal

Gucci R, Lodolini EM, Rapoport HF. 2007. Productivity of olive trees with different water status and crop load. J. Hort. Sci. Biotechnol. 82, 648-656.

Guerfel M, Mansour MB, Ouni Y, Guido F, Boujnah D, Zarrouk M. 2012. Chemical composition of virgin olive oils from the Chemlali cultivar with regard to the method of the olive tree propagation. Grasas Aceites 63, 290-295.

Iniesta F, Testi L, Orgaz, F, Villalobos FJ. 2009. The effects of regulated and continuous deficit irrigation on the water use, growth and yield of olive trees. Eur. J. Agron. 30, 258-265.

Ismail AS, Stavroulakis G, Metzidakis J. 1999. Effect of irrigation on the quality characteristics of organic olive oil. Acta Hort. 474, 687-689.

Kamal-Eldin A. 2006. Effect of fatty acids and tocopherols on the oxidative stability of vegetable oils. Eur. J. Lipid Sci. Technol. 58, 1051-1061.

Laübli MW, Bruttel PA. 1986. Determination of the oxidative stability of fats and oils by the Rancimat method. J. Am. Oil Chem. Soc. 63, 792-795.

Magliulo V, d'Andria R, Lavini A, Morelli G, Patumi M. 2003. Yield and quality of two rainfed olive cultivars 
following shifting to irrigation. J. Hort. Sci Biotechnol. 78, 15-23.

Matos LC, Cunha SC, Amaral JS, Pereira JA, Andrade PB, Seabra RM, Oliveira MBPP. 2007b. Chemometric characterization of three varietal olive oils (Cvs. Cobrançosa, Madural and Verdeal Transmontana) extracted from olives with different maturation indices. Food Chem. 102, 406-414.

Matos LC, Pereira JA, Andrade PB, Seabra R M, Oliveira MBPP. 2007a. Evaluation of a numerical method to predict the polyphenols content in monovarietal olive oils. Food Chem. 102, 976-983.

Menendez JA, Papadimitropoulou A, Vellon L, Colomer R, Lupu R. 2006 . A genomic explanation connecting "Mediterranean diet", olive oil and cancer: Oleic acid, the main monounsaturated fatty acid olive oil, induces formation of inhibitory "PE3 transcription factor PEA3 DNA binding site" complexes at the Her-2/neu (erB-2) oncogenese promoter in breast, ovarian and stomach cancer cells. Eur. J. Cancer 42, 2425-2432.

Moriana A, Pérez-López D, Gómez-Rico A, Salvador MD, Olmedilla N, Ribas F, Fregapane G. 2007. Irrigation scheduling for traditional, low-density olive orchards: Water relations and influence on oil characteristics. Agric. Water Manage 87, 171-179.

Motilva MJ, Tovar MJ, Romero MP, Alegre S, Girona J. 2000. Influence of regulated deficit irrigation strategies applied to olive trees (Arbequina cultivar) on oil yield and oil composition during the fruit ripening period. $J$. Sci. Food Agric. 80, 2037-2043.

Mousa YM, Gerasopoulos D, Metzidakis I, Kiritsakis A. 1996. Effect of altitude on fruit and oil quality characteristics of "Mastóides" olives. J. Sci. Food Agric. 71, 345-350.

Myers BJ. 1988. Water stress integral a link between short-term stress and long term growth. Tree Physiol. 4, 315-323.

Nergiz C, Engez Y. 2000.Compositional variation of olive fruit during ripening. Food Chem. 69, 55-59.

Owen RW, Mier W, Giacosa A, Hull WE, Spiegelhalder B, Bartsch H. 2000. Phenolic compounds and squalene in olive oils: The concentration and antioxidant potential of total phenols, simple phenols, secoiridoids, lignans and squalene. Food Chem. Toxicol. 38, 647-659.

Pastor M, Castro J, Manrique T, Gómez Beltrán L. 1996.Crecimiento del fruto, formación de aceite y producción del olivar regado con diferentes programas de riego por goteo en Andalucía Frutic. Prof. 76, 6-23.

Patumi M, d'Andria R, Fontanazza G, Morelli, G, Giori P, Sorrentino G. 1999. Yield and oil quality of intensively trained trees of three cultivars of olive under different irrigation regimes. J. Hort. Sci. Biotechnol. 74, 729737.

Patumi M, d'Andria R, Marsilio V, Fontanazza G, Morelli G, Lanza B. 2002. Olive and olive oil quality after intensive monocone olive growing (Olea europaea L., cv. Kalamata) in different irrigation regimes. Food Chem. 77, 27-34.

Pérez-Jiménez F, Ruano J, Perez-Martinez P, LopezSegura F, Lopez-Miranda J. 2007. The influence of olive oil on human health: not a question of fat alone. Mol. Nutr. Food Res. 51, 1199-1208.
Romero C, García P, Brenes M, Garcia A, Garrido A. 2002. Phenolic compounds in natural black Spanish olive varieties. Eur. Food Res. Technol. 215, 489-496.

Rondanini DP, Castro, DN, Searles PS, Rousseaux MC. 2011. Fatty acid profiles of varietal virgin olive oils (Olea europaea L.) from mature orchards in warm arid valleys of Northwestern Argentina (La Rioja). Grasas Aceites 62, 399-409.

Salvador MD, Aranda F, Fregapane G. 1999. Contribution of chemical components of Cornicabra virgin oils to oxidative stability. A study of three successive crop seasons. J. Am. Oil Chem. Soc. 76, 427-432.

Stefanoudaki E, Chartzoulakis K, Koutsaftakis A, Kotsifaki F. 2001. Effect of drought stress on qualitative characteristics of olive oil of cv Koroneiki. Grasas Aceites 52, 202-206.

Stefanoudaki E, Williamas M, Chartzoulakis K, Harwood J. 2009. Effect of Irrigation on Quality Attributes of Olive Oil. J. Agric. Food Chem. 57, 7048-7055.

Tognetti R, D'Andria R, Sacchi R, Lavini A, Morelli G, Alvino A. 2007. Deficit irrigation affects seasonal changes in leaf physiology and oil quality of Olea europaea (cultivars Frantoio and Leccino). Ann. Appl. Biol. 150, 169-186.

Tovar MJ, Motilva MJ, Romero MP. 2001. Changes in the phenolic compositionf virgin olive oil from young trees (Olea europaea L. cv. Arbequina) grown under linear irrigation strategies. J. Agric. Food Chem. 49, 5502-5508.

Tovar MJ, Romero MP, Alegre S, Girona J, Motilva MJ. 2002. Composition and organoleptic characteristics of oil from Arbequina olive (Olea europaea L) trees under deficit irrigation. J. Sci. Food Agric. 82, 17551763.

Tovar MJ, Romero M P, Girona J, Motilva MJ. 2002. L-Phenylalanine ammonia-lyase activity and concentration of phenolics in developing olive (Olea europaea L. CV. Arbequina) fruit grown under different irrigation regimes. J. Sci. Food Agric. 82, 892-898.

Salvador MD, Aranda F, Fregapane G. 1999. Contribution of chemical components of Cornicabra virgin oils to oxidative stability. A study of three successive crop seasons. J. Am. Oil Chem. Soc. 76, 427-432.

Servilli M, Esposto S, Lodolini E, Selvaggini R, Taticchi A, Urbani S, Montedoro G, Serravalle M, Gucci R. 2007. Irrigation effects on quality, phenolic composition, and selected volatiles of virgin olive oils $\mathrm{Cv}$. Leccino. J. Agric. Food Chem. 55, 6609-6618.

Vázquez-Roncero A, Janer del Valle $C$, Janer del Valle L. 1973. Determinación de los polifenoles totales en aceite de oliva. Grasas Aceites 243,50-357.

Vinha AF, Ferreres F, Silva BM, Valentão P, Gonçalves A, Pereira JA, Oliveira MB, Seabra RM, Andrade, PB. 2005. Phenolic profiles of Portuguese olive fruits (Olea europaea L.): Influences of cultivar and geographical origin. Food Chem. 89, 561-568.

Wahbi S, Wakrim R, Aganchich B, Tahi H, Serraj R. 2005. Effects of partial root zone drying (PRD) on adult olive tree (Olea europaea) in field conditions under arid climate. I. Physiological and agronomic responses. Agric. Ecosyst. Environ. 106, 289-301.

Recibido: 20/6/12 Aceptado:23/10/12 